\title{
SKALA PRIORITAS PEMBANGUNAN EKONOMI \\ KAMPUNG MAKBALIM DISTRIK SALAWATI KABUPATEN SORONG
}

\author{
Ummu Salmah 1) \\ ${ }^{1)}$ Dosen Fakultas Ilmu Sosial dan Ilmu Politik Universitas Muhammadiyah Sorong \\ Jalan Pendidikan No 27 Kota Sorong \\ Email : ummusalmahumsorong@gmail.com
}

\begin{abstract}
Abstrak
Akses terhadap kesempatan pendidikan dan pelatihan untuk warga kampung Makbalim boleh dikata kurang, dalam arti kurang mendapatkan perhatian khususnya dari kalangan pemerintah (instansi terkait). Hal ini ditandai dengan kurang berhasilnya para petani/warga kampung Makbalim dalam meningkatkan hasil produksinya. Tujuan penelitian ini adalah melihat dari dekat keberhasilan dan kegagalan pembangunan masyarakat transmigrasi di daerah pedesaan/perkampungan; mendata kendala-kendala yang dihadapi dan dirasakan oleh masyarakat, dan kemudian dihimpun dan diberikan suatu solusi alternatif pemecahan; hasil yang ada diseminarkan dengan instansi terkait sebagai bahan kajian ilmiah; implementasi Tri Dharma Perguruan Tinggi, khususnya dharma ketiga yaltu pengabdian kepada masyarakat.Metode pengamatan yang digunakan adalah metode pengamatan lapangan dan kepustakaan, dengan teknis observasi, dan wawancara. Hasil dari penelitian ini adalah pembangunan daerah dalam rangka meningkatkan taraf hidup, peningkatan pendapatan serta kegiatan penduduk Kampung Makbalim merupakan salah satu proses pembangunan yang terjadi bergerak maju, bukan hanya dikonsepkan sebagai usaha pemerintah daerah akan tetapi diperlukan adanya partisipasi aktif dari warga itu sendiri. Dan yang tak kalah pentingnya ketergantungan manusia dengan sumber sosiainya untuk memberdayakan sumber-sumber yang ada baik dalam bidang ekonomi, sosial budaya, pertahanan dan keamanan dan sebagainya yang dapat menghasilkan kepentingan masyarakat; fasilitas umum yang mempunyai pengaruh besar terhadap kehidupan warga masyarakat di Kampung Makbalim dalam rangka peningkatan pelayanan yang optimal, dimana dan pelayanan tersebut dapat memberikan kontribusi besar bagi peningkatan taraf hidup masyarakat dan keberhasilan pemenintah daerah serta tercapainya tujuan pembangunan seperti yang telah dicita-citakan; pembangunan berskala prioritas yang harus dilaksanakan merupakan suatu proses yang berawal dari kondisi infrastruktur yang ada di Kampung Makbalim.
\end{abstract}

Kata Kunci : skala prioritas, pembangunan ekonomi, kampung 


\section{PENDAHULUAN}

\section{Latar Belakang}

Dalam hal kebijakan tidak langsung untuk menanggulangi kemiskinan dan memberdayakan ekonomi rakyat, program-program Inpres Pembangunan untuk daerah pedesaan yang telah cukup berhasil dimasa lalu perlu lebih ditingkatkan, disempurnakan dan dikembangkan. Ini menyangkut peningkatan dan penyempurnaan pengalokasian dana, sistem perbantuan dan pengkoordinasiannya, disamping efektivitas dalam pelaksanaan program-program yang bersangkutan.

Sehubungan dengan itu, dalam upaya meningkatkan kemampuan guna menghasilkan nilai tambah dan pemberdayaan masyarakat miskin, khususnya yang tinggal dan hidup di daerah pedesaan, perlu penyempurnaan dan perbaikan akses terhadap berbagai hal, akses-akses tersebut diantaranya adalah :

1. Akses terhadap sumber daya fisik;

2. Akses terhadap sumber daya pembiayaan;

3. Akses terhadap teknologi yang tepat guna;

4. Akses terhadap informasi pasar (Gunawan Sumodiningrat, 1996)

Dari 4 (empat) akses tersebut diatas yang tak kalah pentingnya adalah akses terhadap kesempatan pendidikan dan pelatihan, akan tetapi akses ini mengalami kendala, dimana pendidikan dan palatihan untuk warga kampung Makbalim boleh dikata kurang, dalam arti kurang mendapatkan perhatian khususnya dari kalangan pemerintah (instansi terkait). Hal ini ditandai dengan kurang berhasilnya para petani/warga kampung Makbalim dalam meningkatkan hasil produksinya. Dengan demikian kendala-kendala yang dihadapi oleh petani/warga masyarakat transmigrasi Kampung Makblim perlu mendapat perhatian pemerintah daerah dalam hal ini Dinas Kependudukan (Eks Dinas Transmigrasi) sebagai instansi teknis pembinaan warga transmigrasi seiring dengan pelaksanaan otonomi daerah. Oleh karena itu pemerintah daerah harus efektif baik secara procedural maupun peran aktif, hal ini perlu dilakukan agar tidak ada anggapan dari warga transmigrasi bahwa keberadaan mereka sudah tidak ada kaitannya dengan pemerintah. Keberhasilan mereka pada lokasi-lokasi pemukiman mencerminkan keberhasilan proyek pembangunan nasional yang telah dianggarkan dalam APBN (Anggaran Pendapatan Belanja Negara).

Indikator peningkatan perekonomian desa dapat terwujud, jika saja pembangunan daerah yang akan dilaksanakan yang meliputi berbagai sektor, seperti : Sarana dan prasarana, kondisi sosial budaya, fasilitas umum, pelayanan kepada masyarakat, dan keadaan ekonomi daerah dibenahi secara sistematis dan kontinyu.

\section{Tujuan}

1. Melihat dari dekat keberhasilan dan kegagalan pembangunan masyarakat transmigrasi di daerah pedesaan/perkampungan.

2. Mendata kendala-kendala yang dihadapi dan dirasakan oleh masyarakat, dan kemudian dihimpun dan diberikan suatu solusi alternatif pemecahan.

3. Hasil yang ada diseminarkan dengan instansi terkait sebagai bahan kajian ilmiah.

4. Implementasi Tri Dharma Perguruan Tinggi, khususnya dharma ketiga yaltu pengabdian kepada masyarakat. 


\section{METODOLOGI PENELITIAN}

\section{Metode Pengamatan}

Metode pengamatan yang digunakan adalah metode pengamatan lapangan dan kepustakaan, dengan teknis

1. Observasi, yaltu pengamatan secara Iangsung terhadap 5 (lima) sektor Sarana dan prasarana, kondisi sosial budaya, fasilitas umum, pelayanan kepada masyarakat dan keadaan ekonomi.

2. Wawancara, yaitu mewawancarai langsung warga masyarakat yang intinya ke-lima sektor tadi.

\section{Batasan Masalah}

Batasan masalah dalam penulisan ini, terfokus pada hasil Praktek Kerja Lapangan (PKL) di Kampung Makbalim yang meliputi beberapa bidang kajian antara lain : keadaan sarana dan prasarana, kondisi sosial budaya, fasilitas umum, pelayanan kepada masyarakat dan keadaan ekonomi yang mengarah pada skala prioritas pembangunan ekonomi.

\section{III.ANALISA DAN PEMBAHASAN}

\section{Gambaran Umum Kampung Makbalim}

Kampung Makbalim adalah merupakan salah satu kampung yang terletak di sebelah selatan Kecamatan Salawati dengan ibukota Salawati, yang luas wilayahnya sebesar 4x5 $\mathrm{km} 2$, berada pada posisi $0,20^{\circ} \mathrm{LS}, 0,27^{\circ} \mathrm{LU}$, dan $132^{\circ} \mathrm{BB}, 13^{0} \mathrm{BT}$ dengan batas-batas wilayah sebagal berikut :
a. Sebelah Utara
: dengan Kampung Makbusun
b. Sebelah Selatan
: dengan Kampung Makotyamsa
c. Sebelah Barat
: dengan Kampung Yeflio
d. Sebelah Timur
: dengan Kecamatan Beraur

Suhu udara antara $22^{\circ} \mathrm{C}-33^{\circ} \mathrm{C}$ dan Curah hujan rata-rata $3.633 \mathrm{~mm} /$ tahun, sedangkan kelembaban udara rata-rata 84\%/bulan, ketinggian dari permukaan laut dibawah $100 \mathrm{~m}$, dan jarak antara Kampung Makbalim - Kota Sorong \pm 39 km, Kampung Makbalim Kecamatan Salawati Daratan $\pm 20 \mathrm{~km}$.

\section{Keadaan Sarana Dan Prasarana}

\section{Perumahan Masyarakat}

Perumahan masyarakat transmigrasi di Kampung Makbalim sejak penempatannya pada tahun 1981 oleh para transmigran yang didatangkan dari pulau Jawa yaitu Jawa Timur, Jawa Tengah dan Jawa Barat, hingga saat ini kondisinya telah mengalami perubahan $\pm 80 \%$ dari kondisi awal.

2. Lahan

Lahan yang diberikan oleh pemerintah kepada setiap kepala keluarga sebanyak 2 Ha, yang terdiri dan 0,25 Ha lahan pekarangan, 0,75 Ha lahan usaha I, dan 1 hektar lahan usaha II.

3. Sarana Jalan

Khusus sarana jalan seperti poros jalan yang menghubungkan antara kampung yang satu dengan kampung yang lain, saat ini kondisinya tidak memenuhi syarat (tidak layak pakai), sementara jalan lingkungan yang digunakan sebagai jalan alternatif dan kantong produksi untuk memasarkan hasil produksi saat ini masih dalam taraf pengerasan yaitu swadaya masyarakat dengan konstruksi tanah liat, sehingga pada musim hujan kondisi jalan tersebut becek dan licin. Apatah lagi jarak antara tempat-tempat hasil produksi dengan poros jalan cukup 
jauh, mengakibatkan masyarakat dalam memasarkan hasil produksi pertanian, perkebunan dan industri mengalami hambatan.

4. Jembatan

Jembatan pada poros jalan dan jalan lingkungan yang ada di K.ampung Makbalim kondisinya dalam keadaan rusak dan memerlukan penanganan secara konkrit oleh pemerintah dalam hal ini Pemerintah Daerah (instansi teknis).

5. Drainase I Saluran Air (Parit)

Guna menjamin terciptanya lingkungan yang bersih, sehat dan aman, salah satu hal yang sangat essensial adalah drainase, saluran air (parit). Drainase, saluran air (parit) yang ada di Kampung Makbalim kondisinya tidak jauh berbeda dengan sarana dan prasarana lainnya, oleh karena itu perlu penanganan dan perbaikan, mengingat hingga saat ini kondisinya tidak berfungsi (tidak dapat digunakan).

\section{Kondisi Sosial Budaya}

Kondisi sosial budaya Kampung Makbalim yang jumlah penduduknya berdasarkar, data kantor Kampung Makbalim per Nopember 2001 sebanyak 477 kepala keluarga (KK) atau 1.892 jiwa yang terdiri dari laki-laki 998 jiwa dan perempuan 894 jiwa, dan jumlah penduduk transmigrasi tersebut sebahagian besar didominasi transmigrasi asal pulau Jawa, yaitu sebesar 95\% dan transmigrasi lokal sebesar 5\%.

1. Agama

Kehidupan beragama di Kampung Makbalim terjalin rukun dan damai, dengan mengedepankan suasana saling toleransi dan saling menghormati antara pemeluk agama yang satu dengan pemeluk agama yang lain. Dengan terjalinnya kehidupan antar ummat beragama yang baik dalam pengertian tidak pernah terjadi dan tidak akan terjadi konflik horisontal, terbukti dengan adanya kegiatan gotong royong yang sering dilaksanakan oleh warga. Adapun agama yang dianut oleh warga Kampung Makbalim sebahagian besar beragama Islam, yaitu sebanyak 95\%, Protestan 3\%, Katholik 1\%, Hindu-Budha $1 \%$.

2. Pendidikan

Tingkat pendidikan warga Kampung Makbalim secara umum rendah, hal ini dapat dilihat pada tabel berikut :

Tabel 1. Data Pendidikan warga Kampung Makbalim

\begin{tabular}{clc}
\hline No 1 & \multicolumn{1}{c}{ U r a i a n } & Jumlah (orang) \\
\hline 1. & Sekolah Dasar (SD) & 593 \\
\hline 2. & Sekolah Lanjutan Tk Pertama (SLTP) & 281 \\
\hline 3. & Sekolah Lanjutan Tk. Atas (SLTA) & 179 \\
\hline 4. & MTS & 12 \\
\hline 5. & Madrasah Aliyah & 5 \\
\hline 6. & STM & 3 \\
\hline 7. & Diploma (D2/D3) & 9 \\
\hline 8. & Sarjana & 11 \\
\hline
\end{tabular}

Sumber: Kantor Kampung Makbalim Nopember 2017 
Sedangkan profesi warga yang jumlah penduduknya sebanyak 1.892 jiwa, sebahagian besar berprofesi sebagai petani dan buruh. Berikut tabel profesi warga Kampung Makbalim :

Tabel 2. Data Profesi warga Kampung Makbalim

\begin{tabular}{clc}
\hline No. & \multicolumn{1}{c}{ Uraian } & Jumlah (Orang) \\
\hline 1. & Pegawal Negeri Sipil (PNS) & 35 \\
2. & Guru Swasta & 15 \\
3. & Wiraswasta & 36 \\
\hline & Sumber Kantor Kampung Makbalim Nopember 2017
\end{tabular}

\section{Kesenian dan Organisasi Kepemudaan}

Kesenian yang ada di Kampung Makbalim, disamping kesenian kuda lumping sebagai konsekwensi dan mayoritas penduduknya dari pulau jawa, juga ditemukan kesenian khas Papua, yaltu tarian yospan. Sedangkan organisasi kepemudaannya adalah karang taruna, sebagai wadah menghimpun para pemuda kampung untuk menumbuhkembangkan aktivitas kearah yang positif.

\section{Fasilitas Umum}

Fasilitas umum yang dimiliki oleh warga Kampung Makbalim, sebagai wadah pengembangan dan pembinaan, baik mental jasmani maupun rohani adalah sebagai berikut :

1. Fasllitas Pendidikan

Fasilitas pendidikan seperti taman kanak-kanak (TK) sebanyak 2 (dua) buah, dimana sampai saat ini masih dikelola oleh masyarakat (swasta) dengan menggunakan fasilitas (menumpang) pada kantor kampung/balai kampung dalam hal proses belajar-mengajar. Sekolah Dasar (SD) sebanyak 3 (tiga) buah, yang terdiri dari 1 (satu) buah yang pengelolaannya oleh pihak swasta, dan yang 2 (dua) buah pengelolaannya oleh pemerintah (SD Inpres).

Madrasah setingkat Sekolah Lanjutan Tingkat Pertama (SLTP) sebanyak 1 (satu) buah dan dikelola oleh swasta dan menggunakan (memiliki) bangunan sendiri.

2. Fasilitas Kesehatan

Fasilitas kesehatan yang digunakan oleh warga sebagal tempat melakukan pengobatan adalah 1 (satu) unit Puskesmas Pembantu, dengan juru rawat 1 (satu) orang dan bidan kampung 1 (satu) orang.

3. Fasilitas Ibadah

Fasilitas ibadah warga Kampung Makbalim, sebagal tempat melaksanakan hubungan vertikal kepada sang pencipta dan pengembangan mental rohani warga dapat dilihat pada tabel berikut :

Tabel 3. Fasilitas Ibadah Kampung Makbalim

\begin{tabular}{clc}
\hline No. & \multicolumn{1}{c}{ U r a i a n } & Jumlah \\
\hline 1. & Mesjid I Mushollah & 2 buah \\
2. & Gereja & 2 buah \\
3. & Pura / Wihara & -- \\
\hline \multicolumn{2}{l}{ Sumber Kantor Kampung Makbalim Nopember 2017}
\end{tabular}

Khusus untuk gedung gereja yang terdiri dan 2 (dua) buah, dimana 1 (satu) buah milik GKI (Gereja Kristen Injili) dan 1 (satu) buah lagi milik GPDI (Gereja Pantekosta di Indonesia) Jemaat Tiberias yang jumlah jemaatnya \pm ada 6 KK (30 
jiwa), kondisi bangunannya $\pm 40 \%$ telah terselesaikan, dimana pembangunan geraja tersebut murni swadaya warga jemaat.

Sedangkan untuk pembangunan gedung mesjid/musholla yang letaknya di RK.IVRT.II, sejak didirikan tahun 1982 dimana pembangunannya dilaksanakan atas swadaya masyarakat dengan melibatkan beberapa donatur telah digunakan oleh warga.

4. Fasilitas-fasilitas Umum Lainnya

a. Fasilitas Kantor Kampung

Kantor kampung yang sekaligus berfungsi sebagai balai kampung sebanyak 1 (satu) buah yang konstruksinya semi permanen.

b. Fasilitas Air Bersih

Fasilitas air bersih serta bak penampungannya telah ada, namun fasilitas tersebut hanya digunakan selama 6 (enam) bulan, itupun belum merata dinikmati oleh warga Kampung Makbalim. Dan hingga saat ini fasilitas tersebut tidak berfungsi lagi.

c. Fasilitas Gedung Pembibitan

Fasilitas ini sejak dibangun hingga saat ini belum diresmikan penggunaannya apalagi pemanfaatannya, sehingga memberikan kesan tidak optimal dalam arti tidak effisien dan tidak efektif.

d. Lapangan Sepak Bola

Fasilitas tersebut digunakan oleh warga kampung khususnya para pemuda kampung sebagal tempat berolah raga, namun pemanfaatannya belum optimal, oleh karena kondisi lapangan tidak memenuhi persyaratan.

e. Fasilitas Irigasi

Kampung Makbalim sebagal kampung yang mengharap turunnya hujan, telah dibuatkan embun/kolam penampung air untuk kebutuhan pengairan bagi sawahsawah warga sebanyak 10 (sepuluh) unit, namun 2 unit embun berfungsi dan 8 unit embun dalam kondisi rusak (tidak berfungsi).

f. Pos Kamling

Fasilitas pos kamling sesual dengan instruksi dan Binmas Polres, bahwa setiap RT baik diperkotaan maupun di pedesaan/perkampungan wajib mengamankan lingkungannya masing-masing. Oleh karena itu di Kampung Makbalim telah dibuat Pos Kamling di setiap RK maupun RT.

g. WC Umum

Salah satu wujud dan kesehatan lingkungan adalah WC umum, hal ini telah dilakukan oleh pemenintah dengan membangun WC umum, namun kondisinya tidak jauh berbeda dengan fasilitas air bersih tadi, dimana warga hanya menikmati selama 6 (enarn) bulan dan hingga saat ini tidak difungsikan lagi.

\section{Pelayanan Kepada Masyarakat}

1. Aparatur Pemerintah

Indikasi dan aparatur pemerintah disini adalah petugas penyuluh lapangan (PPL), baik PPL pertanian, PPL kesehatan maupun aparat kampung.

Seperti telah diuraikan pada bab sebelumnya bahwa warga masyarakat Kampung Makbalim adalah masyarakat transmigrasi baik transmigrasi yang datang dan luar Kabupaten Sorong ataupun transmigrasi lokal yang selama dalam pembinaan Departemen Transmigrasi (pada saat itu), boleh dikatakan relatif baik, hal ini dapat dilihat dari perhatian Pemerintah dengan memberikan jaminan hidup, dan penyuluhan kepada warga Kampung Makbalim secara kontinyu sehingga dapat 
hidup secara mandiri. Namun sejak tahun 1987 dimana pembinaan warga masyarakat transmigrasi Kampung Makbalim dialihkan kepada Pemerintah Daerah dalam hal ini Pemda Kabupaten Sorong, pelayanan aparatur Pemerintah semakin berkurang, hal tersebut dapat dibuktikan dengan adanya sebagian warga Kampung Makbalim telah bekerja di sektor lain seperti industri (Pabrik Kayu Lapis) untuk melanjutkan kelangsungan hidupnya hal ini merupakan konsekwensi kurangnya perhatian Pemerintah untuk melakukan pembinaan kepada warga, baik pembinaan yang bersifat kegiatan pembangunan (fisik) maupun pembinaan non-fisik (penyuluhan), padahal warga transmigrasi sesuai program pemerintah secara umum disamping pelaksanaan target, juga mempunyai tujuan lain, salah satu tujuan tersebut adalah pemberdayaan dibidang pertanian. Petugas penyuluh lapangan (PPL) yang merupakan personil atau perpanjangan tangan yang ditugaskan oleh pemerintah untuk melaksanakan penyuluhan dengan memberikan informasi-informasi yang tepat guna kepada masyarakat khususnya di Kampung Makbalim belum berfungsi secara maksimal.

Satu contoh pada bidang pertanian, tenaga penyuluh seyogianya mampu menjelaskan cara-cara peningkatan produksi pertanian dengan merubah pola pertanian tradisional dengan pola pertanian moderen. Dan hasil pengamatan dilapangan secara umum Petugas Penyuluh Lapangan (PPL) sudah tidak melakukan tugas pokok dan fungsinya lagi.

2. Pelayanan Kesehatan dan Keluarga Berencana

Pada dasarnya sejak pemerintah merencanakan pelaksanaan transmigrasi, para transmigran telah dibekali dengan pengetahuan-pengetahuan, seperti pengetahuan tentang arti pentingnya kesehatan dan keluarga berencana (KB). Namun inisiatif pemerintah bukan sampai disitu saja akan tetapi perlu kesinambungan pelaksanaannya hingga warga transmigrasi memahami akan arti pentingnya kesehatan dan keluarga berencana. Hal ini terlihat bahwa secara umum warga masyarakat Kampung Makbalim mempunyal 3 - 4 orang anak dalam satu keluarga, ini akibat mulai lemahnya kontrol atau penyuluhan tentang kesehatan dan keluarga berencana PPL kesehatan juga perlu memberikan pemahaman tentang alat kontrasepsi, karena secara umum sesuai hasil pengamatan kami dengan warga, alat kontrasepsi yang banyak digunakan warga Kampung Makbalim untuk melaksanakan Program Keluarga Berencana adalah suntikan dan Pil. Sementara penyakit yang sering dialami masyarakat Kampung Makbalim adalah penyakit malaria, dimana penyakit tersebut merupakan penyakit yang secara umum terdapat di Papua atau kabupaten dan kota Sorong.

Fasilitas obat-obatan yang tersedia di Puskesmas Pembantu Desa Makbalim sangat terbatas, sehingga banyak warga masyarakat yang menggunakan pengobatan secara tradisional.

\section{Keadaan Ekonomi}

1. Bidang Pertanian dan Perkebunan

Sesual dengan salah satu visi dan misi penempatan transmigrasi, yaitu beradaptasi dan melakukan usaha pada sektor pertanian, maka sebagian besar penduduk Kampung Makbalim mempunyai mata pencaharian sebagai petani atau bercocok tanam. Adapun tanaman pertanian yang dikelola adalah :

a. Tanaman Pangan (padi)

b. Tanaman semusim seperti : pisang, kacang tanah, kacang hijau, kacang panjang, tomat, cabe dan jenis sayur-sayuran. 
Namun belakangan ini hasil panen khususnya padi tidak berhasil, hal ini disebabkan keadaan alam, seperti sawah tadah hujan (cuaca) juga hama yang menyerang, sehingga banyak warga masyarakat yang enggan mengelola lahan pertanian khususnya tanaman padi. Sedangkan untuk tanaman semusim masih diusahakan oleh masyarakat untuk keperluan sehari-hari dan selebihnya dipasarkan (dijuaI), hanya saja sistem yang digunakan masih tradisional.

2. Bidang Peternakan

Bidang peternakan di Kampung Makbalim saat ini yang banyak ditekuni oleh warga masyarakat adalah peternakan sapi, selain itu ada juga peternakan ayam yang dijalani sebagai usaha sampingan, yang kebanyakan adalah untuk konsumsi sendiri.

Bidang peternakan pada awalnya pemerintah memberikan bantuan (Banpres) berupa ternak kepada warga masyarakat dengan sistem pemberiannya adalah pembagian bantuan berdasarkan undian kepada Kepala Keluarga (KK), yaitu 1 (satu) KK memperoleh bantuan berupa 1 ekor sapi, dengan tujuan agar dapat meningkatkan kesejahteraannya. Ada juga sistem lain yang sering digunakan yaitu sistem Gado (IJON), artinya pemberian bantuan yang pada waktu tertentu penerima bantuan berkewajiban untuk mengembalikannya. Namun sistem bantuan tersebut saat ini sudah tidak ada lagi, sehingga masyarakat menggunakan modal sendiri untuk membeli ternak. Pada bidang peternakan sistem pengembangan dan pemeliharaan yang dilakukan atau diterapkan warga di Kampung Makbalim masih menggunakan sistem tradisional, hal ini akibat kurangnya perhatian pemerintah untuk rnengefektifkan PPL peternakan.

3. Bidang Perikanan Air Tawar

Berdasarkan hasil pengamatan kami di Kampung Makbalim, sektor perikanan menjadi salah satu tumpuan kehidupan bagi beberapa warga kepala keluarga. Usaha perikanan yang dikelola oleh warga masyarakat adalah kolam ikan mas. Berbeda dengan sektor lain yang diusahakan secara sederhana dan alamiah, sektor usaha ini (ikan mas) warga masyarakat mengusahakan dengan pola yang lebih baik, walaupun yang menggeluti usaha perikanan ini hanya beberapa orang warga saja. Namun kontribusi usaha perikanan ikan mas cukup memberikan nilai yang signifikan, disamping usaha-usaha lain yang dikembangkan seperti : warung makan, dimana dirumah makan itulah warga yang usahanya memelihara ikan mas menjual panen ikannya, dan sebahagian dipasarkan ke Kota Sorong.

4. Bidang Produksi

Bidang produksi berdasarkan pengamatan yang kami lakukan, yaitu pengelolaan bahan mentah menjadi barang jadi seperti produksi gula merah. Produksi ini oleh masyarakat cukup menjamin/menunjang perekonomian keluarga secara kontinyu. Akan tetapi usaha produksi gula merah ini hanya dilakukan oleh sebagian kecil warga.

Sementara bahan baku dasar yang digunakan untuk memproduksi gula tersebut yaitu dengan menyadap pohon kelapa cukup tersedia. Namun antusias warga masyarakat untuk menggeluti usaha ini cukup kecil, hal ini terlihat dengan adanya warga masyarakat menekuni secara sendiri-sendiri dan dengan sistem yang masih tradisional serta adanya warga masyarakat yang menyewakan pohon kelapanya untuk dijadikan bahan baku yang menghasilkan legen untuk produksi gula merah, dimana satu pohon kelapa dikontrak/sewa dengan harga Rp. 25.000 ,-/tahun. 
Sebagai contoh, pak Minarto seorang warga yang berusaha memproduksi gula merah, menyadap rata-rata 10 pohon kelapa dalam sehari untuk keperluan bahan baku. Dan 10 pohon kelapa yang disadap setiap hari, hasil produksinya dapat mencapai 5-7 kg gula merah.

Hasil tersebut dijual/dipasarkan kepasar sentral Sorong seharga Rp. 4.500/kg. Keuntungan yang diperoleh dapat diperhitungkan sebagai berikut (Misalkan menghasilkan gula merah sebanyak $7 \mathrm{~kg}$ ).

Hasil penjualan Rp. 4.500 x 7 kg Rp. 31.500,-

Biaya-biaya produksi :

- Kayu bakar dan gula pasir Rp. 10.000,-

Biaya transportasi ke Sorong :

- Personil 1 orang PP Rp. 6.000,-

- Barang Rp. 1.000,-

Retribusi masuk pasar :

- Orang (pedagang) Rp. 1.000,-

- Barang Rp. 1.000,-

- Lain-lain Rp, 2.000,--

Jumlah Biaya (Kost) Rp. 21.000,-

Keuntungan yang diperoleh (Laba) Rp. 10.500,-

Catatan: Keuntungan tersebut belum diperhitungkan

dengan tenaga kerja sendiri.

5. Bidang Pemasaran

Dalam memasarkan hasil produksinya warga masyarakat Kampung MakbaIim, menggantungkan pada pasar lokal yaltu masyarakat setempat dan pasar yang ada di Kota Sorong, namun dalam hal pemasaran ke kota Sorong sering mengalami hambatan karena faktor transportasi, dimana dan Kampung Makbalim ke kota Sorong yang jaraknya $\pm 39 \mathrm{~km}$ dengan waktu tempuh \pm 90 menit, akibat kondisi jalan akhir-akhir ini mengalami kerusakan mengakibatkan waktu tempuh ke kota Sorong menjadi bertambah dan kurangnya mobilitas penduduk dari dan ke Kampung Makbalim sebagai alternatif pemasaran.

\section{Masalah Yang Dihadapi}

Dari beberapa uraian tentang gambaran umum Kampung Makbalim yang telah diuraikan pada Bab II diatas, dimana tentunya telah memberikan masukan tentang infrastruktur pembangunan dan kondisi kegiatan masyarakat yang pada giirannya merupakan suatu proses bahwa untuk menuju skala prioritas pembangunan perlu menyikapi dan mengkondisikan masalah-masalah yang ada baik dalam infrastruktur maupun kondisi masyarakat. Hal ini menjadi faktor-faktor penghambat dalam memacu pembangunan serta peningkatan kesejahteraan. Satu hal yang perlu kita ketahui bersama bahwa, masalah-masalah yang timbul adalah merupakan suatu sistem yang saling terkait satu dengan yang lainnya. OIeh karena itu perlu disikapi secara arif dan bijaksana.

Adapun masalah-masalah pokok yang menjadi prioritas dalam penulisan ini adalah sebagal berikut

A. Sarana Dan Prasarana

Masalah-masalah pokok yang timbul khususnya dan sektor sarana dan prasarana yang meliputi perumahan masyarakat, jalan, lahan, jembatan dan drainase (parit) dan hasil pengamatan kami ada 4 (empat) masalah yang perlu mendapat perhatian guna menunjang peningkatan kesejahteraan warga, antara lain: 
1. Poros jalan umum, dan jalan lingkungan, dimana dalam jarak tertentu masih ditemui/dijumpai jalan yang berlubang-lubang yang kondisinya sangat memprihatikan (rusak) dan hingga saat ini belum ada perhatian dari Pemerintah Daerah untuk memperbaiki jalan tersebut dan bahkan pemeliharaannya masih diserahkan kepada warga masyarakat (swadaya masyarakat) termasuk jalan lingkungan menuju ke lokasi transmigrasi swakarsa mandiri (TSM) yang jaraknya \pm $2 \mathrm{~km}$ dan poros jalan.

2. Jembatan, baik jembatan yang ada pada poros jalan maupun jembatan pada jalan Iingkungan, konstruksinya masih darurat (kayu), dimana perlu segera mendapat perhatian bukan saja dan warga masyarakat yang setiap saat menikmatinya, akan tetapi dibutuhkan perhatian Pemerintah Daerah, agar transportasi masyarakat dari kantong produksi, seperti Pertanian, perkebunan, peternakan dan industri tidak mengalami hambatan.

3. Dranase (parit)

Dari hasil pengamatan kami kondisi drainase (parit) perlu segera diperbaiki guna memperlancar aliran air, sehingga bila hujan turun tidak terjadi banjir.

4. Lahan

Lahan usaha II yang diperuntukkan kepada warga transmigrasi okasinya jauh dari pemukiman penduduk sehingga warga enggan mengelola lahan tersebut.

B. Kondisi Sosial Budaya

Masalah-masalah yang timbul pada sektor sosial budaya secara umum tidak ada, namun sebagal warga masyarakat yang penduduknya terdiri dan berbagai suku, agama, tingkat pendidikan dan lain sebagainya, tentunya terdapat perbedaan-perbedaan yang mengarah pada masalah-masalah, walaupun prosentasenya kecil. Adapun masalahmasalah yang ada pada sektor sosial budaya sesuai hasil pengamatan kami adalah :

1. Tingkat pendidikan, artinya penduduk Kampung Makbalim yang sebahagian besar berpendidikan Sekolah Dasar (SD), perlu segera diambil Iangkah-langkah konkrit, guna peningkatan tingkat pendidikannya dan kepada warga yang telah berpendidikan tinggi dapat dioptimalkan.

2. Profesi warga, dimana dan 1.892 jiwa penduduk Kampung Makbalim baru 86 orang atau $4,5 \%$ yang berprofesi atau yang berpenghasilan tetap sedangkan selebihnya adalah petani dan buruh.

3. Tidak adanya ijin penjualan kayu oleh masyarakat untuk membantu pendanaan pembangunan gedung gereja dan kesejahteraan warga.

4. Kurangnya perhatian Pemerintah terhadap penerbitan sertifikat tanah guna membangun Mushollah diatas tanah berukuran $15 \times 10 \mathrm{~m}$, hasil hibah warga muslim RK IV - RT II.

5. Kurangnya perhatian Pemerintah terhadap kesenian, khususnya tarian tradisional khas Papua (Yospan).

C. Fasilitas Umum

Fasilitas umum yang ada di Kampung Makbalim sesuai hasil pengamatan kami, pemanfaatannya oleh warga masyarakat memiliki beberapa masalah serius yang perlu disikapi dan ditanggulangi antara lain :

1. Secara umum untuk fasilitas pendidikan mulai dari tingkat Sekolah Dasar (SD) hingga Sekolah Lanjutan Tingkat Pertama (SLTP) dan Madrasah perlu mendapat perhatian baik bangunan maupun buku-buku penunjang. Satu contoh pendidikan pra sekolah/taman kanak-kanak (TK), dalam proses belajar-mengajar masih menggunakan fasilitas balai kampung dengan pengelolaan warga masyarakat. 
2. Sekolah Dasar (SD) khususnya yang ada di TSM saat ini hanya sampai pada kelas 5, dan kondisi bangunan sangat sederhana hasil swadaya warga masyarakat yang dikelola oleh 5 (lima) orang tenaga pengajar, yang terdiri dari 4 orang guru PNS dan 1 orang guru swasta.

3. Puskesmas pembantu, khususnya di lokasi TSM.

4. Pernbangunan fasilitas ibadah gedung gereja GPDI jemaat Tiberias yang penyelesaian fisiknya baru mencapai $\pm 40 \%$.

5. Penggunaan air bersih, WC umum yang hanya dimanfaatkan selama 6 bulan sejak dibangun, dan hingga kini tidak berfungsi lagi akibat kerusakan seperti : Bak air retak, air tidak mengalir dan lain-lain.

6. Penggunaan gedung pembibitan pertanian yang belum dimanfaatkan sejak dibangun.

7. Penerangan Listrik yang belum menyentuh sebahagian warga, khususnya warga Transmigrasi Swakarsa Mandiri (TSM).

D. Pelayanan Kepada Masyarakat

1. Kurangnya perhatian pemerintah (instansi terkait) dalam merespon keluhankeluhan warga masyarakat tentang masalah-masalah baik dibidang pertanian, perkebunan, peternakan, perikanan maupun industri, sehingga para warga kampung telah beralih profesi menjadi buruh pabrik (pabrik kayu lapis PT. Hendrison Iriana).

2. Kurangnya perhatian aparatur pemerintah (PPL Kesehatan dan bidan kampung) seperti respon tenaga medis dalam memberikan pelayanan kesehatan kepada warga yang menggunakan kartu sehat.

3. Kurangnya persediaan obat-obatan yang ada di Puskesmas Pembantu.

E. Keadaan Ekonomi

1. Bidang Pertanian dan Perkebunan

a. Pengairan (irigasi) yang berskala teknologi belum ada, sehingga tanaman padi sulit tumbuh dengan baik sedang tanaman musiman dengan tidak menentunya musim yang ada di Sorong, artinya jika terjadi hujan akan mengakibatkan banjir dan jika terjadi kemarau akan mengakibatkan terbatasnya air.

b. Penggunaan metode pertanian dan perkebunan masih bersfat tradisional, sehingga hasil produksi tidak maksimal.

c. Sering adanya gangguan hama tikus, babi, dan rusa.

d. Tingginya biaya produksi hasil pertanian dan perkebunan sehingga tidak sesuai dengan hasil panen yang didapat.

2. Bidang Peternakan

a. Pemeliharaan hewan ternak masih dilakukan dengan sistem tradisional yaitu mengandalkan proses alamiah, akibatnya pengembangbiakan hewan ternak menjadi lambat.

b. Kurangnya dukungan pemerintah daerah (instansi terkait) dalam menjaga dan meningkatkan pengembangan hewan ternak secara lebih baik (berskala teknologi).

c. Masyarakat tidak memiliki modal usaha.

3. Bidang Perikanan

a. Animo masyarakat dalam menekuni usaha di bidang perikanan khususnya usaha ikan mas kurang, hal ini disebabkan karena modal, lahan usaha yang tidak sesuai serta persediaan air yang kurang. Walaupun usaha tersebut mempunyai prospek yang lebih baik. 
b. Masyarakat belum mampu mengembangkan usaha perikanan dengan memasukkan unsur wisata dan hiburan, karena keterbatasan modal dan kemampuan.

4. Bidang Produksi

Bidang ini seringkali orang mengidentikkan dengan industri, sehingga kendala yang dihadapi oleh masyarakat di Kampung Makbalim dalam bidang produksi adalah :

a. Minimnya keterampilan yang dimiliki oleh warga, sehingga dalam memproduksi suatu produk biaya yang dikeluarkan tidak seimbang (balance).

b. Warga masih menggunakan sistem tradisional sesuai bakat alamiah, sehingga produksi yang dihasilkan masih relatif kecil.

c. Persediaan resources yang produktif (pohon kelapa) masih terbatas.

d. Tidak semua warga masyarakat memperoleh kesempatan mendapatkan bantuan modal usaha, akibat prosedur yang sulit.

5. Bidang Pemasaran

a. Komoditi hasil-hasil produksi yang dipasarkan kurang bisa bersaing dengan produksi dan luar.

b. Stabilitas harga tidak menentu akibat over produksi dan hasil-hasil produksi para petani.

c. Belum maksimalnya koperasi dalam membantu pengadaan dan penyaluran hasilhasil produksi.

d. Kurangnya informasi tentang prospek komoditi yang sangat diperlukan pasar.

\section{Alternatif Pemecahan Masalah}

Pembangunan daerah sebagai tolok ukur pembangunan nasional dalam era otonomi dan reformasi sekarang ini perlu segera diaktualisasikan, sehingga pemerataan pembangunan disegala aspek dapat terwujud. Pemerintah daerah diharapkan segera dapat melakukan perubahan kearah perbaikan dan segera dapat mewujudkan good governance yang merupakan persyaratan bagi setiap pemerintahan dalam mencapai tujuan.

Pemerintah Daerah Kabupaten Sorong dalam visinya menyatakan "Pemerintah Daerah Kabupaten Sorong, menjadi fasilitator dalam peningkatan ekonomi, sosial budaya dan politik melalui pengelolaan sumber daya alam yang didukung oleh infrastruktur yang memadal sehingga terwujud masyarakat yang lebih sejahtera. Sedangkan misi Pemerintah Daerah Kabupaten Sorong adalah :

1. Memberikan pelayanan yang nyata kepada masyarakat agar mampu meningkatkan pendapatan masyarakat, kesejahteraan masyarakat melalui pencapaian swasembada di bidang produksi pertanian tanaman pangan, peternakan, perikanan dan perkebunan dengan tidak mengabaikan aspek Iingkungan.

2. Memacu industri kecil dan menengah serta memberdayakan ekonomi kerakyatan.

3. Peningkatan kemampuan masyarakat dan akuntabilitas kinerja aparatur pemerintah melalul pendidikan formal dan non-formal, peningkatan keamanan dan ketertiban dalam masyarakat, peningkatan penanganan masalah sosial dalam masyarakat, meningkatkan efisiensi dan efektifitas administrasi dan pengelolaan keuangan daerah.

Dengan adanya visi dan misi pemerintah daerah kabupaten sorong setelah melihat faktual yang riil dilapangan khususnya di Kampung Makbalim, maka dan gambaran umum yang kemudian melihat permasalahan yang timbul tentunya perlu solusi pemecahan masalah. Oleh karena itu untuk mewujudkan tujuan yang hendak dicapai dalam skala prioritas pembangunan ekonomi perlu dilakukan secara sistem, 
artinya infrastruktur yang ada dengan kendala-kendalanya seyogianya dibenahi lebih dulu, sebab pencapaian tujuan yang hendak dicapai itu merupakan suatu proses, dan salah satu proses itu adalah perencanaan dan kordinasi serta penyelesaian-penyelesaian masalah dan 5 (lima) sektor yang telah diuraikan pada bab-bab sebelumnya.

Acuan kebijaksanaan pembangunan, baik pembangunan daerah maupun pembangunan masyarakat desa/transmigrasi selalu berorientasi pada berbagai kebijaksanaan nasional yang telah ada, antara lain :

1. Pancasila sebagai landasan idiil dan Undang-Undang Dasar 1945 sebagal landasan konstitusional/operasional yang berupa kebijaksanaan umum penyelenggaraan pemerintah dan pembangunan.

2. Tap MPR No. II/MPR/1999 tentang Garis-Garis Besar Haluan Negara.

3. Undang-Undang Republik Indonesia No. 3 Tahun 1997 dan No. 5 Tahun 1974 tentang Pokok-Pokok Transmigrasi.

4. Undang-Undang Republik Indonesia No. 10 Tahun 1982 tentang Perhubungan Kependudukan dan Pembangunan Masyarakat Sejahtera.

5. Undang-Undang Republik Indonesia No. 3 Tahun 1992 tentang Ketentuanketentuan Pokok Transmigrasi.

6. Undang-Undang Republik Indonesia No, 5 Tahun 1975 tentang Pemerintah Desa.

7. Undang-Undang Republik Indonesia No. 22 Tahun 1999 tentang Pemerintah Daerah.

8. Undang-Undang Republik Indonesia No. 25 Tahun 1999 tentang Perimbangan Keuangan antara Pemerintah Pusat dan Daerah.

9. Peraturan Pemerintah Republik Indonesia No. 42 Tahun 1973 tentang Penyelenggaraan Transmigrasi.

10. Peraturan Pemerintah Republik Indonesia No. 25 Tahun 2000 tentang Kewenangan Pemerintah dan Kewenangan Propinsi Sebagai Daerah Otonom.

11. Kebaksanaan Pembangunan Daerah.

A. Sarana Dan Prasarana

Sektor tersebut sesual masatah-masalah yang telah diuraikan pada bab sebelumnya perlu segera direalisasikan dengan mengambil langkah-Iangkah konkrit sebagai solusi alternatif pemecahan masalah.

1. Poros Jalan Umum dan Jalan Lingkungan

Poros jalan umum yang pada awal mulanya aspal, namun belakangan ini telah mengalami kerusakan akibat volume jalan yang sering dilalui kendaran berat dan pada jarak tertentu kondisi jalan berlubang-lubang, sementara untuk jalan Iingkungan yang konstruksinya masih tanah liat, dimana jika terjadi hujan akan mengakibatkan licin, maka solusi yang dapat diambil sebagai alternatif pemecahannya adalah untuk poros jalan umum segera dilaksanakan pengaspalan kembali, sedang untuk jalan lingkungan dapat dilakukan dengan penimbunan serta sebagai langkah tahap pengerasan jalan.

Khusus untuk jalan lingkungan menuju lokasi TSM perlu perhatian khusus, artinya jalan Iingkungan tersebut sudah perlu dilakukan pengaspalan melihat kondisi jalan yang telah memenuhi kriteria, disamping itu jaraknya yang begitu jauh $\pm 2 \mathrm{~km}$ poros jalan.

2. J e m b a t a n

Jembatan yang ada pada poros jalan umum maupun jembatan yang ada pada jalan lingkungan dengan konstruksi yang masih darurat (kayu), seyogianya dapat dilakukan dengan sistem permanen, sehingga dapat beraplikasi dengan dranase 
(parit) dalam hal aliran air. Hal ini dapat dilakukan dengan mengoptimalkan masyarakat setempat dan pemerintah daerah sebagal donatur sebagai konsekwensi transparansi yang menjunjung tinggi azaz efisiensi dan efektifitas.

3. Drainase (Parit)

Walaupun perbaikan jalan telah dilakukan, konstruksi jembatan telah permanen, namun drainase (parit) tidak dilakukan rehabilitasi pada hakekatnya adalah kegiatan yang sia-sia. Oleh karena dari tiga komponen sektor ini adalah saling terkait. Pembuatan drainase (parit) harus dilakukan dengan jalan merehabilitasi drainase (parit) yang telah ada, sehingga aliran air akan lancar dan jalan-jalan tidak akan mengalami genangan-genangan air walaupun turun hujan.

4. L a h a n

Memotivasi warga masyarakat agar mengelola lahan usaha II sebagai lahan produksi untuk peningkatan kesejahteraan masyarakat. Jika hal-hal tersebut diatas dilakukan, maka masalah-masalah dalam sektor ini dapatlah terjawab, mengingat jalan, jembatan, drainase (parit) dan lahan sangat bermanfaat bagi kelangsungan aktivitas pembangunan warga desa terutama untuk meningkatkan kesejahteraannya.

B. Kondisi Sosial Budaya

Seiring dengan komitmen Pemerintah dan visi serta misi Pemerintah Daerah Kabupaten Sorong pada sektor sosial budaya, yaitu : Peningkatan sumber daya manusia (SDM), peningkatan kesejahteraan, pembinaan masyarakat dan lain sebagainya, maka alternatif pemecahan masalah dan sektor ini adalah pemerintah daerah (instansi terkait) harus proaktif melakukan pembinaan seperti :

1. Pendidikan, mensosialisasikan keberadaan, manfaat dan mekanisme, seperti pendidikan luar sekolah kejar paket A, paket B, SMP terbuka, dan SMA terbuka.

2. Memberdayakan dan memanfaatkan kaum intelektual tingkat pendidikan tinggi (sarjana) sebagai tenaga pendamping pembangunan di kampung dengan konsekwensi honor yang diberikan dapat disesuaikan dengan kondisi kerja mereka (UMR) atau memanfaatkan tenaga mereka dalam peningkatan sosial kehidupan masyarakat dengan suntikan dana pelaksanaan kegiatan ekonomi (JPS).

3. Memberikan keteramplan khusus kepada warga, sehingga dengan keterampilan tersebut warga memiliki profesi dan dengan sendirinya warga mempunyai penghasilan tetap guna kesejahteraan hidupnya.

4. Untuk menjaga mis-komunikasi antar warga, seyogianya memberikan kesempatan kepada warga untuk mengelola hasil hutan, seperti kayu dalam bentuk kayu olahan.

5. Memberikan kesempatan kepada warga untuk membina mental rohani dengan membangunan tempat ibadah.

6. Membina dan menumbuh-kembangkan kesenian-kesenian yang telah ada dengan mengupayakan tarian tradisional khususnya tarian Yospan dalam kurikulum pendidikan mulai pada tingkat SD, SLTP, dan SLTA sebagal tarian daerah.

C. Fasilitas Umum

Menjawab permasalahan yang dihadapi oleh warga masyarakat tentang fasilitas umum yang begitu kompleks adalah melalui beberapa alternatif, antara lain :

1. Bidang Pendidikan

Bidang ini memegang peranan penting untuk mencerdaskan bangsa namun jika bidang ini terabaikan, maka sumber daya manusia yang diharapkan akan minim. Oleh karena itu penyediaan fasliltas pendidikan sesuai kendala-kendala yang ada harus dapat dicermati dan direalisasikan pembangunannya. Khusus untuk Sekolah 
Dasar (SD) di lokasi TSM yang keberadaannya baru sampai pada kelas V perlu eksen konkrit dari pemerintah daerah untuk menuntaskan keberadaan Sekolah Dasar (SD) tersebut.

2. Bidang Kesehatan

Keberadaan Puskesmas Pembantu yang saat ini keberadaannya ada di pusat kampung, kurang efektif bagi warga masyarakat yang ada di lokasi TSM karena jarak antara puskesmas pembantu dengan lokasi TSM $\pm 3 \mathrm{~km}$. Hal ini perlu penyediaan fasihtas kesehatan khususnya warga TSM di lokasi TSM.

3. Rumah Ibadah

Rumah ibadah khususnya gedung gereja GPDI jemaat Tiberias yang penyelesaian fisiknya baru mencapai $\pm 40 \%$, sesuai hasil pengamatan dilapangan para jemaat meminta bantuan 1 (satu) unit mesin chain saw untuk digunakan mengolah hasil hutan.

4. Fasilitas Umum Lainnya

Fasilitas umum lainnya seperti : Air bersih, bak air, WC umum, gedung pembibitan, dan penerangan listrik telah ada, namun fasilitas umum tersebut penggunaannya tidak maksimal oleh warga sesual perencanaan awal

a. Air Bersih, Bak Air, dan WC Umum.

Fasilitas ini sejak dibangun penggunaannya tidak produktif, karena hanya digunakan selama 6 (enam) bulan itupun tidak merata dinikmati oleh warga Kampung Makbalim dan hingga saat ini fasilitas-fasilitas tersebut tidak berfungsi lagi. Sebelum fasilitas-fasilitas ini ada, khususnya air bersih warga masyarakat kampung Makbalim mengkonsumsi air hujan. Oleh karena itu keberadaan fasilitas-fasilitas tersebut sangat dibutuhkan oleh warga, dengan demikian perlunya merehabilitasi fasilitas-fasilitas tersebut sehingga dapat digunakan dan dinikmati oleh warga kembali.

b. Gedung Pembibitan

Gedung pembibitan yang ada di Kampurig Makbalim menurut pengamatan kami kurang produktif, dimana fasilitas pendukung dan pembibitan tersebut seperti air sangat sulit, sehingga memberikan indikasi bahwa perencanaan dan koordinasi tidak prima. Seyogianya gedung tersebut ditempatkan pada daerah/kampung yang sesuai (memenuhi fasilitas yang dibutuhkan dalam setiap gedung pembibitan).

c. Penerangan Listrik

Seperti warga masyarakat pada umumnya, warga kampung Makbalim khsusnya warga TSM juga menginginkan penerangan listrik, oleh karena itu diharapkan pemerintah (instansi terkait) dapat merespon keinginan warga TSM tersebut dengan menyediakan fasilitas penerangan.

D. Pelayanan Kepada Masyarakat

Dari permasalahan-permasalahan yang terhimpun pada sektor ini, sesuai hasil pengamatan di lapangan alternatif pemecahannya adalah :

1. Kepada para PPL diharapkan pro aktif sesuai tugas dan fungsinya.

2. Kepada para PPL tersebut dapat diberikan tunjangan fungsional sebagai konsekwensi motifasi dalam pelaksanaan tugas.

3. Dengan adanya subsidi kesehatan yang diberikan oleh Pemerintah kiranya di peruntukkan sesual perencanaan yang telah digariskan.

E. Keadaan Ekonomi

1. Bidang Pertanian dan Perkebunan 
Hasil pengamatan kami ada beberapa hal yang dapat dijadikan alternatif untuk memecahkan permasalahan-permasalahan tersebut :

a. Saluran air ditata dengan menggunakan irigasi (pengairan) dengan teknis yang baik, namun jika hal itu tidak memungkinkan, mengingat faktor alam, maka perlu dibuatkan sistem pompanisasi dengan menjaga kelangsungan pemanfaatannya.

b. Supaya tenaga-tenaga PPL dapat berfungsi secara maksimai, dengan mengadakan hubungan atau koordinasi kerja yang harmonis dengan pihak aparat terkait, serta memberikan penyuluhan atau pelatihan tentang penggarapan lahan pertanian yang lebih baik dan modern (intensifikasi pertanian).

c. Agar Pemerintah mengupayakan secara intensif melalui instansi terkait untuk mengadakan bimbingan tepat guna untuk pengolahan lahan pertanian, sehingga lahan tidur yang banyak terdapat di kampung Makbalim dapat dimanfaatkan menjadi lahan produktif.

d. Untuk meningkatkan produktifitas pertanian, hendaknya pemerintah memberikan bantuan peralatan pertanian yang lebih modern.

e. Menjajaki kemungkinan pembukaan areal perkebunan dengan skala besar dengan melibatkan petani setempat, misal kelapa sawit, coklat, kopi dan sebagainya.

2. Bidang Peternakan

a. Sangat diharapkan dari pihak aparat kampung dan tenaga-tenaga penyuluh dibidang peternakan agar senantiasa dapat memberikan pengarahan atau penyuluhan kepada para peternak. Kalaupun dipelihara secara tradisional, para penyuluh dapat tetap terus memberikan perhatian terhadap kualitas kesehatan ternak melalul suntikan dan pemeriksaan rutinitas, agar dapat memberikan hasil yang baik.

b. Memberikan bantuan permodalan dan bimbingan untuk menjajaki kemungkinan pengembangan usaha ternak lain yang sesuai dengan kondisi tingkungan.

3. Bidang Perikanan

a. Agar masyarakat dapat menjalankan usaha peternakan ikan mas ini maka perlu diupayakan permodalan dan sarana pengairan yang memadai agar warga dapat membuat kolam ikan.

b. Agar pemasaran hasil ikan yang menggantungkan pada rumah makan setempat dapat lebih meningkat, maka perlu perbaikan sarana jalan yang saat ini kondisinya rusak berat agar lebih menarik bagi masyarakat Kota Sorong untuk mengunjungi rumah makan ikan mas di kampung Makbalim tersebut.

c. Pemerintah perlu mendorong dan menjajaki kemungkinan dikembangkannya sektor perikanan itu menjadi bisnis pariwisata dan hiburan misalnya : kolam pemancingan.

4. Bidang Produksi

a. Untuk mendorong kearah usaha yang lebih modern dan profesional, maka pemerintah melalui instansi terkait perlu memberikan bimbingan dan pelatihan kepada masyarakat agar mereka memiliki kemampuan melihat perspektif usaha yang Iebih baik serta mampu mengelola secara modern/profesional. 
b. Agar pihak pemberi modal usaha (donatur) dapat memberikan prosedur peminjaman yang lebih sederhana dan mudah dipahami oleh warga transmgrasi.

c. Pemerintah dapat memberikan motivasi kepada warga untuk menanam pohon kelapa hibryda, sebagai pensuplay bahan baku (legen) untuk peningkatan produksi gula merah.

5. Bidang Pemasaran

Kampung Makbalim yang letaknya cukup jauh dari Kota Sorong, sehingga untuk pemasaran hasil produksinya tidak terlepas dari beberapa hal pokok, seperti Transportasi (angkutan), tempat pemasaran (pasar), jalan. Ketiga hal tersebut perlu mendapat perhatian serius dalam menunjang bidang pemasaran, baik dari pemerintah kampung maupun pemerintah daerah (instansi teknis) yang terkait.

Disamping itu perlunya upaya-upaya lain seperti :

a. Komoditi yang dihasilkan harus dapat bersaing dengan komoditi dari luar dengan jalan, pemerintah (instansi terkait) dapat memberikan bimbingan pengetahuan yang lebih baik guna peningkatan produksi dan kualitasnya.

b. Perlunya aparatur pemerintah (PPL) mengarahkan kepada warga masyarakat dalam memproduksi hasil-hasil, seperti pertanian, perkebunan, perikanan, peternakan dan industri, sehingga tidak terjadi over produksi terhadap satu komoditi.

c. Mengoptimalkan keberadaan Koperasi dalam membantu warga masyrakat.

d. Mengoptimalkan peranan juru penerang masyarakat (Jupen) dalam aspek informasi yang dibutuhkan oleh masyarakat khususnya tentang informasi pasar.

Solusi alternatif pemecahan masalah yang telah ditawarkan dan berbagai sektor tersebut diatas diyakini memberikan nilai positif dan pengembangan warga kampung Makbalim jika benar-benar diaktualisasikan dan direalisasikan. Namun perlu disadari dengan adanya kondisi bangsa dan negara yang sedang dilanda krisis multi dimensi, yang salah satunya adalah krisis moneter, maka perlunya diambil skala prioritas pembangunan sebagai solusi afternatif pemecahan masalah warga kampung Makbalim guna peningkatan kesejahteraan antara lain :

1. Peningkatan sarana dan prasarana transportasi yang menghubungkan Kota Sorong dengan kampung Makbalim. Hal tersebut adalah dalam rangkaian kegiatan pemenuhan kebutuhan masyarakat, baik untuk pemenuhan pemasaran maupun dalam rangka pemenuhan kebutuhan hidup masyarakat.

2. Penyediaan fasilitas umum berupa air bersih yang menjadi salah satu faktor untuk memenuhi kebutuhan sehari-hari dan peningkatan kesehatan masyarakat.

3. Peningkatan sarana dan prasarana dibidang kesehatan baik berupa pelayanan kesehatan secara langsung maupun berupa penyuluhan, sehingga masyarakat mengerti pola-pola hidup sehat.

4. Peningkatan sarana dan prasarana pertanian, baik berupa irigasi, bibit-bibit unggul dan penyuluhan pertanian, hal ini merupakan faktor yang tak kalah pentingnya untuk peningkatkan perekonomian masyarakat di kampung Makbalim. 


\section{IV.KESIMPULAN}

Berdasarkan uraian bab-bab terdahulu maka dapat ditarik beberapa kesimpulan sebagai berikut :

1. Pembangunan daerah dalam rangka meningkatkan taraf hidup, peningkatan pendapatan serta kegiatan penduduk Kampung Makbalim merupakan salah satu proses pembangunan yang terjadi bergerak maju, bukan hanya dikonsepkan sebagai usaha pemerintah daerah akan tetapi diperlukan adanya partisipasi aktif dari warga itu sendiri. Dan yang tak kalah pentingnya ketergantungan manusia dengan sumber sosiainya untuk memberdayakan sumber-sumber yang ada baik dalam bidang ekonomi, sosial budaya, pertahanan dan keamanan dan sebagainya yang dapat menghasilkan kepentingan masyarakat.

2. Fasilitas umum yang mempunyai pengaruh besar terhadap kehidupan warga masyarakat di Kampung Makbalim dalam rangka peningkatan pelayanan yang optimal, dimana dan pelayanan tersebut dapat memberikan kontribusi besar bagi peningkatan taraf hidup masyarakat dan keberhasilan pemenintah daerah serta tercapainya tujuan pembangunan seperti yang telah dicita-citakan.

3. Pembangunan berskala prioritas yang harus dilaksanakan merupakan suatu proses yang berawal dari kondisi infrastruktur yang ada di Kampung Makbalim.

\section{DAFTAR PUSTAKA}

I Gusti Ketut Swalem, 1990. Pemerintahan Desa. Satya Wacana, Semarang Cetakan Pertama.

Pemerintah Daerah Propinsi Irian Jaya, 1995. Petunjuk Teknis Pelaksanaan Program Bantuan Pembangunan Desa Tertinggal.

Rukmadi Warsito, dkk, 1995. Dan Daerah Asal Sampal Benturan Budaya Ditempat Pemuk/man. PT. Raja Grafindo Persada, Jakarta Cetakan kedua.

San Afri Awang dkk, 1995. Program IDT dan pemberdayaan Masyarakat. Penerbit Aditya Media.

Sondang P. Siagian, 1983. Administrasi Pembangunan. PT. Gunung Agung, Jakarta :

Sri Edi Swasono, dan Masri Singarimbun, 1986. Transmigrasi di Indonesia 1905-1985 Universitas Indonesia (UI - Press) Jakarta : 
Lampiran I

\section{STRUKTUR ORGANISASI \\ KAMPUNG MAKBALIM KECAMATAN SALAWATI \\ KABUPATEN SORONG}

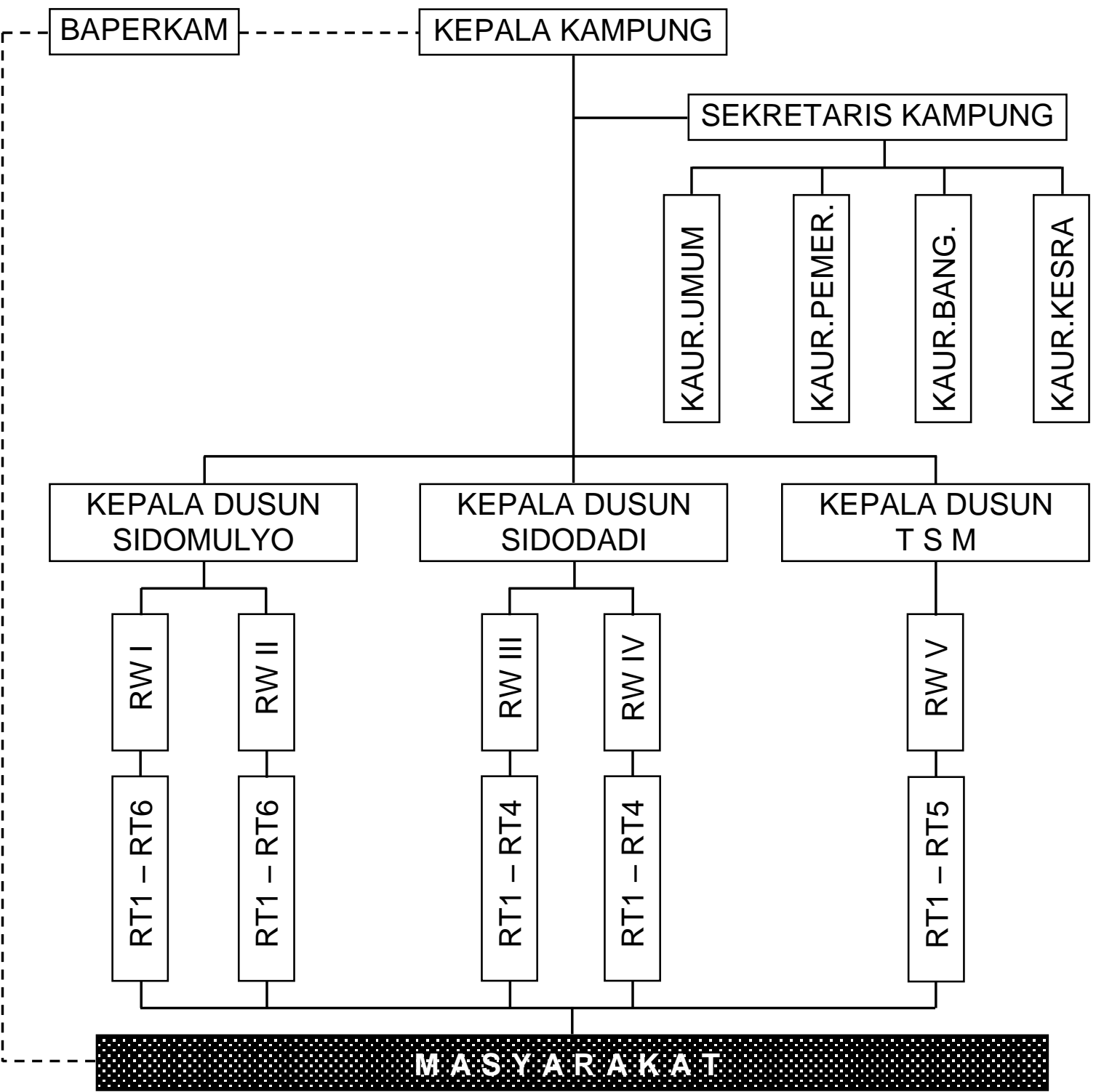

Ket :

Hub. Langsung

Hub. Tidak Langsung 


\section{REKOMENDASI}

Pembangunan Kabupaten Sorong adalah merupakan bagian integral dan Pembangunan Nasional yang bertujuan untuk mewujudkan masyarakat yang adil dan makmur secara materil dan spritual sebagaimana diamanatkan dalam Pembukaan Undang-Undang Dasar 1945. Hakekat Pembangunan Nasional adalah pembangunan manusia Indonesia seutuhnya dan pembangunan masyarakat Indonesia seluruhnya. Hal ini mengandung arti bahwa pembangunan harus dilaksanakan merata diseluruh tanah air dan benar-benar dapat dirasakan oleh seluruh rakyat sebagai perbaikan tingkat hidup yang berkeadilan sosial.

Pembangunan Kabupaten Sorong yang merupakan subsistem Pembangunan Nasional, mengandung arti bahwa kegiatan-kegiatan pembangunan yang dapat dilaksanakan di Kabupaten Sorong sangat dipengaruhi oeh kegiatan Pembangunan Nasional dan kondisi obyektif daerah. Kondisi obyektif daerah Kabupaten Sorong menuntut adanya kebijakan pembangunan yang diprioritaskan. Dengan diberlakukannnya Undang-Undang Republik Indonesia Nomor 22 Tahun 1999 tentang Otonomi Daerah Undang-Undang Republik Indonesia Nomor 25 Tahun 1999 tentang Perimbangan Keuangan antara Pemerintah Pusat dan Daerah, serta berkenaan dengan komitmen Pemerintah Daerah Kabupaten Sorong sesuai visi dan misi pembangunan daerah, dimana pembangunan harus dilaksanakan secara merata hingga sampai kepedesaan/kampung. Secara konkrit usaha-usaha Pemerintah Daerah Kabupaten Sorong tersebut telah menunjukkan hasil-hasil yang positif, namun disamping itu terdapat pula kekurangan-kekurangan. Sesual hasil pengamatan mahasiswa STIA AlAmin Sorong pada Praktek Kerja Lapangan (PKL) di Kampung Makbalim dan berdasarkan hasil seminar yang dilaksanakan pada tanggal 15 Januari 2002, maka kami mencoba memberikan masukan-masukan kepada Pemerintah Daerah Kabupaten Sorong beserta jajarannya (Dinas Otonom yang terkait) dalam bentuk rekomendasi dan permasalahan-permasalahan yang secara signivikan perlu penangan secara cepat dengan mengusulkan hal-hal sebagai berikut :

1. Merealisasikan pembangunan sarana dan prasarana baik sarana dan prasarana kampung maupun sarana dan prasarana transportasi yang menghubungkan Kota Sorong dengan kampung Makbalim. Guna pemenuhan kebutuhan masyarakat dan percepatan tingkat kesejahteraan warga Kampung Makbalim.

2. Penyediaan fasilitas umum, berupa air bersih sebagai salah satu faktor dominan untuk memenuhi kebutuhan sehari-hari dan peningkatan kesehatan masyarakat.

3. Peningkatan sarana dan prasarana dibidang kesehatan baik berupa pelayanan kesehatan secara langsung maupun berupa penyuluhan, sehingga masyarakat mengerti pola-pola hidup sehat.

4. Peningkatan sarana dan prasarana pertanian, baik berupa irigasi, bibit-bibit unggul dan penyuluhan pertanian, hal ini merupakan faktor yang tak kalah pentingnya untuk meningkatkan perekonomian masyarakat. 
